\title{
Instinctive Fiber- Based Food Packaging Application-A Review
}

\author{
V Gowsalya, R Vanitha and Kavitha* \\ Department of Chemistry, Adhiyaman Arts \& Science College for Women, India \\ *Corresponding author: Kavitha, Department of Chemistry, Adhiyaman Arts \& Science College for Women, India
}

\begin{tabular}{|c|c|}
\hline ARTICLE INFO & ABSTRACT \\
\hline Received: 慧 April 16, 2019 & \multirow{3}{*}{$\begin{array}{l}\text { Purpose of Review: This article focuses on the use Fiber based of active and } \\
\text { intelligent packaging in the food industry and highlights areas wherever these techniques } \\
\text { are being useful to applied for the storage of fresh produce. It is of great significance to } \\
\text { the storage of fresh manufacture and several types of active packages are commercially } \\
\text { accessible. The recent advances in packaging technology have enhanced things together } \\
\text { from a consumer safety perspective and for manufactures as well. Though, there are } \\
\text { numerous areas which necessitate further exploration. The development of toxic free and } \\
\text { degradable or edible packaging materials that are protected for humans as well as for the } \\
\text { environment; more research into regulations governing the appraisal and use of these } \\
\text { technologies worldwide. }\end{array}$} \\
\hline Published: April 23, 2019 & \\
\hline $\begin{array}{l}\text { Citation: V Gowsalya, R Vanitha, Ka- } \\
\text { vitha. Instinctive Fiber- Based Food } \\
\text { Packaging Application-A Review. Bi- } \\
\text { omed J Sci \& Tech Res 17(2)-2019. } \\
\text { BJSTR. MS.ID.002988. }\end{array}$ & \\
\hline
\end{tabular}

Keywords: Cellulose Fiber; Active Packaging; Moisture; Antimicrobial Activity

\section{Introduction}

In current years packaging has developed well beyond its unique function as merely a means of product safety and now plays a key advertising role in upward on shelf appeal, providing product information, and begins brand image and awareness. In addition to its role in the protection, storage, transport and food security, it has developed into an information and communication aid with indisputable economic and social activities [1-4]. Technology advances and environmental controls, and its expansion reflect consumer needs. The crowded food product market in India appears to be the further next level of growth. Stable favorable statistics, such as increased insufficient income, demand for consumer consciousness and processed food, and rapid access to multinational companies. The continued quest for novelty in food and beverage packaging is frequently ambitious by consumer needs and demands influenced by varying global trends, like increased life expectancy, less organizations investing in food manufacture and distribution, and regionally plentiful and diverse food supply. The make use of food packaging is a socioeconomic pointer of the increased spending aptitude of the population or the gross domestic product, as well as regional food availability. Cellulose is the most extensively spread natural polymer and is consequent by a delignification from wood pulp or cotton linters. It is a biodegradable polysaccharide and fiber-based packaging is made from fibrous material naturally virgin pulpwood, improved paper from post-industrial sources (such as: production waste) or post consumer waste (e.g., old corrugated boxes, waste paper and folding cartons, bags). Even though fiber-based packaging has environmental and social impacts, it is completed from a renewable material that can be recycled where amenities exist [5-7].

However, all the impacts crossways a product's and package's provide chain should be measured when making packaging decisions as there are tradeoffs surrounded by different types of packaging materials Active packaging materials are considered to actively maintain or recover the condition of the food either by abolishing unwanted components from the package headspace. Such actions result in an conservatory of shelf life, improved safety and sensory quality and the maintenance of product quality. Unlike, active packaging, traditional packaging plays a dynamic role in food preservation. The major applications have frequently focused on delaying oxidation and controlling moisture migration, respiration rates, microbial growth, aromas and volatile flavors. Moisture control agents assist control water activity, thus reducing microbial growth; eliminate melting water from ice-covered products and blood or fluids from animal protein products; prevent condensation from fresh produce; and remain the rate of lipid oxidation in check .Fiber based material is reduced antimicrobials growth rate and highest population of microorganisms (spoilage and pathogenic) by expanding the lag phase of microbes or inactivating them [8-10]. 


\section{Conclusion}

The food industry has seen huge advances in the packaging sector because its inception in this century with a large amount of active and intelligent innovations occurring during the past century. These advances have led to enhanced food quality and safety. Nowadays fiber-based packaging materials are typically used to pack short shelf life products, such as fresh fruits and vegetables, and extensive shelf life products, like pasta and chips, which do not require very high oxygen or water barrier properties. The recent advances in the packaging technologies have led to incredible growth, development and benefits to the consumers as well as manufacturers. It can be concluded that fiber-based materials offer great probable for the packaging industry. It is although important to realize that a thorough evaluation of the functional properties of a fiber-based material is essential before it can be used as an alternative for conventional film materials.

\section{References}

1. Lord JB (2008) The food industry in the United States. In: Brody AL, Lord J (Eds). Developing new food products for a changing market place. $\left(2^{\text {nd }}\right.$ Edn) Boca Raton, CRS Press, USA, p. 1-23.

2. Brody A (2008) Packaging by the numbers. Food Technology 62(2): 8991.

\section{ISSN: 2574-1241}

DOI: $10.26717 /$ BJSTR.2019.17.002988

Kavitha. Biomed J Sci \& Tech Res

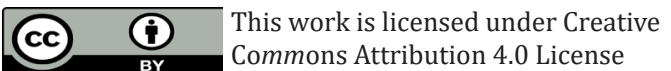

Submission Link: https://biomedres.us/submit-manuscript.php
3. Robertson G (2006) Food packaging principles and practices. ( $2^{\text {nd }}$ Edn). Boca Raton. Taylor \& Francis, pp. 545.

4. Mensitieri G, Di Maio, E, Buonocore, GG, Nedi I, Oliviero M, et al. (2011) Processing and shelf life issues of selected food packaging materials and structures from renewable resources. Trends in Food Science \& Technology 22(2-3): 72-80.

5. Müller CMO, Laurindo, JB, Yamashita F (2011) Effect of nanoclay incorporation method on mechanical and water vapor barrier properties of starch-based films. Industrial Crops and Products 33(3): 605-610.

6. Aday, Mehmet Seckin, Cengiz Caner, Fatih Rahvali (2011) Effect of oxygen and carbon dioxide absorbers on strawberry quality. Postharvest Biology and Technology 62(2): 179-187.

7. Kartal, Serkan, Mehmet Seckin Aday and Cengiz Caner (2012) Use of microperforated films and oxygen scavengers to maintain storage stability of fresh strawberries. Postharvest Biology and Technology 71: $32-40$.

8. Rhim JW, Lee JH, Perry KW Ng (2007) Mechanical and barrier properties of biodegradable soy protein isolate-based films coated with polylactic acid. Food Science and Technology 40(2): 232-238.

9. Sanchez Garcia, Gimenez E, Lagaron JM (2008) Morphology and barrier properties of solvent cast composites of thermoplastic biopolymers and purified cellulose fibers. Carbohydrate Polymers 71(2): 235-244.

10. Siracusa V, Rocculi, P, Romani, S Dalla Rosa M (2008) Biodegradable polymers for food packaging. Trends in Food Science \& Technology 19(12): 634-643.

$\begin{array}{ll}\text { BIOMEDICAL } & \text { Assets of Publishing with us } \\ \text { RESEARCHES } & \text { - Global archiving of articles } \\ & \text { - Immediate, unrestricted online access } \\ & \text { - Rigorous Peer Review Process } \\ \end{array}$

